\title{
COASTAL UPWELLING AND RADIOCARBON-EVIDENCE FOR TEMPORAL FLUCTUATIONS IN OCEAN RESERVOIR EFFECT OFF PORTUGAL DURING THE HOLOCENE
}

\author{
António M Monge Soares \\ Departamento de Química, Instituto Tecnológico e Nuclear, Estrada Nacional 10, 2685-953 Sacavém, Portugal. \\ Corresponding author. Email: amsoares@itn.pt. \\ João M Alveirinho Dias \\ Faculdade de Ciências do Mar e do Ambiente, Universidade do Algarve, Campus de Gambelas, 8000-117 Faro, Portugal. \\ Email: jdias@ualg.pt.
}

\begin{abstract}
This paper focuses on the use of the radiocarbon content of marine shells collected along the Portuguese coast as a proxy for the intensity of coastal upwelling off of Portugal. Differences in the ${ }^{14} \mathrm{C}$ ages of closely associated marine mollusk shells and terrestrial material (charcoal or bones) from several Portuguese archaeological contexts seem to be significant throughout the Holocene. $\Delta \mathrm{R}$ values range from $940 \pm 50$ to $-160 \pm 40{ }^{14} \mathrm{C} \mathrm{yr}$. Five of these values are significantly higher than the modern value $\left(250 \pm 25{ }^{14} \mathrm{C} \mathrm{yr}\right)$, while the remaining values are lower. The modern value was calculated by measuring the ${ }^{14} \mathrm{C}$ content of live-collected, pre-bomb marine mollusk shells. This value is in accordance with an active upwelling of strong intensity that currently occurs off of Portugal. Some primary observations based on data presented here can be made: i) during the Holocene important changes have occurred in the ocean reservoir effect off the Portuguese coast; ii) these fluctuations may be correlated with regional oceanographic changes, namely with changes in the strength of coastal upwelling; and iii) these changes suggest some sort of variability of the climatic factors forcing coastal upwelling off of Portugal.
\end{abstract}

\section{INTRODUCTION}

Along the western coasts of Europe, active upwelling is at present practically restricted to the Atlantic coast of the Iberian Peninsula, particularly from Cape Finisterre to Cape São Vicente (Wooster et al. 1976) and along the south coast of Portugal (Fiúza 1982, 1983). The western coast extends along the $9^{\circ} \mathrm{W}$ meridian between $37^{\circ} \mathrm{N}$ and $43^{\circ} 30^{\prime} \mathrm{N}$, and the southern coast (Algarve) is oriented along $37^{\circ} \mathrm{N}$ between $7^{\circ} 20^{\prime} \mathrm{W}$ and $9^{\circ} \mathrm{W}$ (see Figure 1). The regime of winds strongly correlates with latitudinal migration of the subtropical front and with the dynamics of the Azores anticyclone cells. Hence, the atmospheric circulation associated with the Azores high corresponds to westerly winds off the Atlantic Iberian coast in the winter and to considerably stronger northerly and northwesterly winds in the summer. These northerly summer winds induce Ekman transport offshore along the western coast, i.e. they are clearly upwelling from June to September. The surface water circulation of the southern coast must be considered in relation to the Northeastern Atlantic circulation. Due to the dynamic effect of Cape São Vicente, the upwelled water in the western coast moves southeastward and eastward, creating a quasi-permanent upwelling area around the Cape as a prolongation of the western coastal upwelling system (Fiúza 1982, 1983; Fiúza et al. 1982; Ferreira 1984). When prevailing winds in the Gulf of Cádiz are from the west, the upwelled waters travel east along the southern coast, and a minor upwelling area is found to the east of Cape Santa Maria, Faro (Vargas et al. 2003).

Several upwelling proxies, such as sea surface temperatures (SST) and salinities (Fiúza 1982, 1983; Fiúza et al. 1982; Relvas and Barton 2000; Sánchez and Relvas 2003; Peliz et al. 2002) or diatom accumulation rates, planktonic foraminifera, and $\mathrm{O}$ and $\mathrm{C}$ isotopes (Abrantes 2000; Abrantes et al. 2001), have been used to study this phenomenon. Among them, SST data permit calculation of thermal anomalies of the waters along the coast relative to the central North Atlantic, where isotherms present a consistently zonal distribution (Fiúza 1982, 1983; Fiúza et al. 1982). In addition, the remotely sensed surface thermographies show that shortly after the beginning of a northerly wind cycle, upwelling begins south of all capes on the west Iberian coast and is strongly influenced by the 


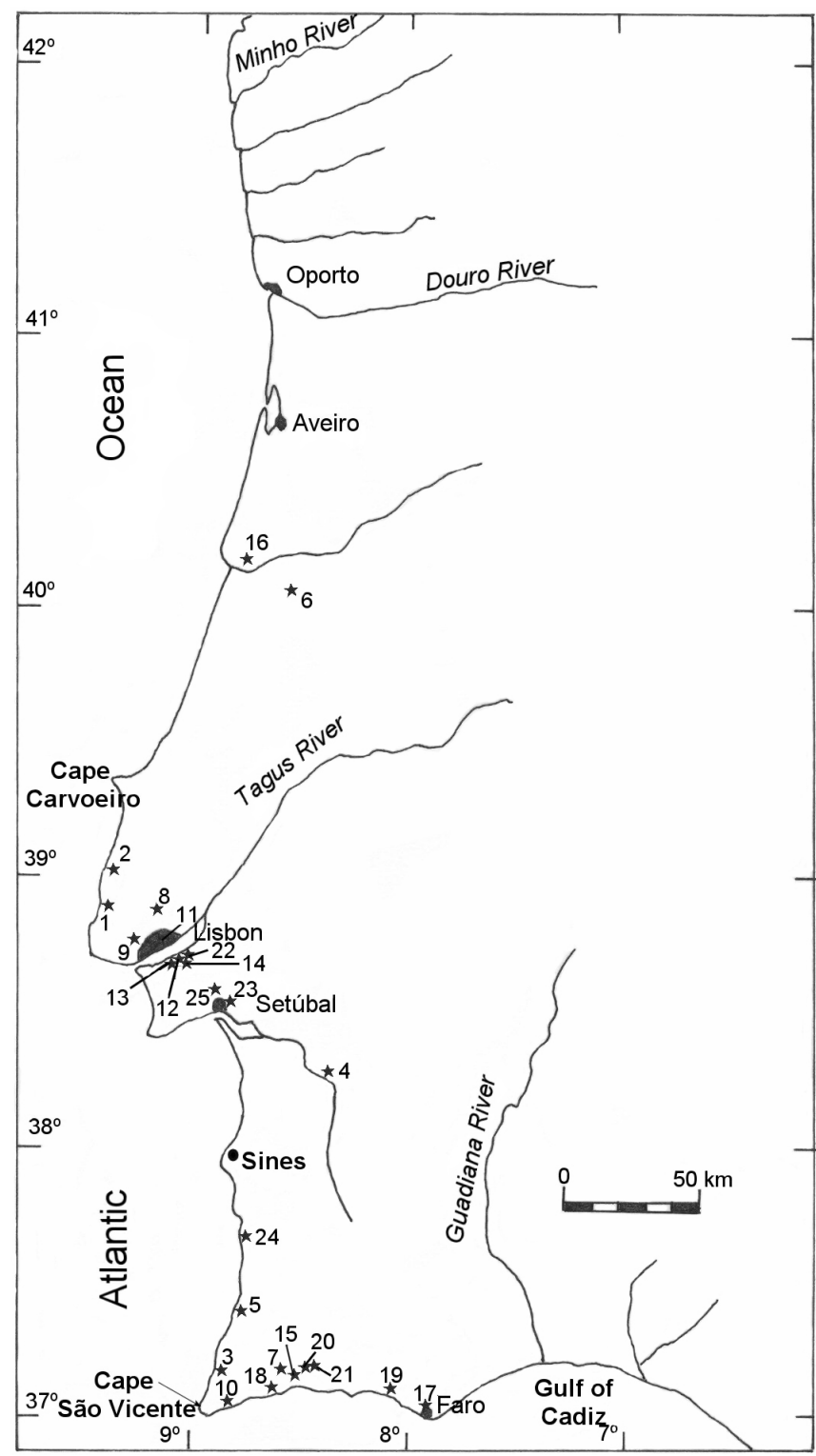

Figure 1 Locations of the sampled archaeological sites identified in Table 1

bathymetry of the shelf-upper slope region. Other factors such as land runoff and local aerological circulations determine the complex upwelling pattern off the Portuguese coast-for instance, in summer, a strong thermal gradient exists between the coastal region of Sines $\left(38^{\circ} \mathrm{N}\right)$ and the continental region at the same latitude, which gives rise to very strong sea breezes. In general terms, it can be stated that upwelling is more pronounced to the south of Cape Carvoeiro $\left(39^{\circ} 20^{\prime} \mathrm{N}\right)$, with a maximum intensity in the Sines coastal region (Ferreira 1984).

As upwelled waters are depleted in radiocarbon relative to sea surface water, the ${ }^{14} \mathrm{C}$ content of marine shells that inhabit coastal regions can be used as an upwelling proxy, since the ocean reser- 
voir is deficient in ${ }^{14} \mathrm{C}$ compared with the atmosphere. Stuiver et al. (1986) modeled the response of the world oceans to atmospheric ${ }^{14} \mathrm{C}$ variations. From this modeling, 2 calibration curves for marine samples have been derived-one related to the deep ocean and the other to the sea surface water (mixed layer). Regional differences in ${ }^{14} \mathrm{C}$ content between the sea surface water of a specific region and the average surface water are due to several causes and anomalies, namely the upwelling of deep water. Thus, a parameter, denoted as $\Delta \mathrm{R}$, can be defined as the difference between the reservoir age of the mixed layer of the regional ocean and the reservoir age of the mixed layer of the average world ocean. Usually, $\Delta \mathrm{R}$ values are determined for a particular geographical region by ${ }^{14} \mathrm{C}$ dating of marine mollusk shells of historic (known) age, collected alive before 1950, i.e. of "pre-bomb" age (Stuiver et al. 1986). Although reservoir ages are time-dependent, $\Delta \mathrm{R}$ is not unless some change of oceanographic conditions restricted to the considered regional ocean has occurred. Since rates of regional upwelling can vary in the course of time and the intensity of the ${ }^{14} \mathrm{C}$ depletion in the mixed layer depends upon the wind-driven coastal upwelling, it is likely that values of $\Delta \mathrm{R}$ can also vary throughout time (Stuiver and Braziunas 1993:155). A $\Delta \mathrm{R}$ value higher than the modern value (i.e. the one determined using marine mollusk shells of historic known age) will probably represent a period of higher-than-modern upwelling rates, and, conversely, periods with lower-than-modern $\Delta \mathrm{R}$ values may represent periods of weaker coastal upwelling. Thus, as a measure of the regional enhancement or depletion of ${ }^{14} \mathrm{C}, \Delta \mathrm{R}$ can also be used as an upwelling proxy, which provides the most direct signal of upwelling activity (Diffenbaugh et al. 2003).

From previous research concerning the coastal upwelling off of Portugal and its variability during the Holocene (Soares 1993), a mean value $\left(250 \pm 25{ }^{14} \mathrm{C}\right.$ yr) for $\Delta \mathrm{R}$ was calculated using shells from marine mollusks collected alive along the Portuguese coast between 1886 and 1937. This mean value is in accordance with the occurrence of an active upwelling of strong intensity as exists today and is valid for the whole Portuguese coast. In compliance with the definition, $\Delta \mathrm{R}$ was assumed to be constant (Stuiver et al. 1986). Nevertheless, the research carried out at that time indicated that before $1300 \mathrm{BP}$, a coastal environment probably existed that was weakly influenced by the upwelling of deep water. After $1100 \mathrm{BP}$, the reservoir age of Portuguese coastal waters seems to have increased to the modern value of $\Delta \mathrm{R}$ in accordance with the occurrence of an active coastal upwelling of strong intensity. These data suggest that between 1300 and $1100 \mathrm{BP}$, a change in certain climatic parameters along the Portuguese coast might have occurred, causing a significant intensification of coastal upwelling off of Portugal (Soares 1993:484).

We have continued the previous research by ${ }^{14} \mathrm{C}$ dating more pairs of closely associated samples of marine shells and charred wood or bones collected from the same stratigraphic level at various excavated Portuguese archaeological sites representing different periods in the Holocene. Our main purpose is not only to clarify the eventual variability of coastal upwelling off of Portugal but also to identify shifts in oceanic circulation, probably coupled with climatic change.

\section{SAMPLING}

Pairs of closely associated archaeological samples (marine shells/charcoal, wood, or bones) from each depositional context were collected from a range of Portuguese archaeological sites. It is assumed that the deposition of both types of samples was simultaneous or, in other words, that the time of death of organisms from both reservoirs was the same.

We tried to eliminate problematical associations by closely consulting the excavators of each sampled site. In order to obtain accurate results, we selected samples from i) single or stratified deposits whose archaeology indicated they had always remained undisturbed and ii) deposits of domestic 
refuse thought to have accumulated rapidly. For Epipaleolithic or Mesolithic shell middens, we took shell and charcoal samples in close stratigraphic proximity.

In some cases, we measured several different shell species or different materials of terrestrial origin (charcoal and bones) from the same archaeological context. Using different shell species, we tried to test not only if their respective ${ }^{14} \mathrm{C}$ dating results were influenced by dietary or habitat preferences of the analyzed mollusks but also to identify eventual outliers. For charcoal samples, it was not possible to undertake any prior anthracological analyses, and in order to overcome the problem of the "old wood effect," which can lead to low or negative $\Delta \mathrm{R}$ values, associated bones were dated whenever possible. Also whenever possible, other contexts from the same archaeological site were ${ }^{14} \mathrm{C}$ dated and the results compared with the data used to calculate $\Delta \mathrm{R}$ in order to verify their reliability.

This methodology was thought to be the most promising to obtain accurate values of $\Delta \mathrm{R}$. A detailed discussion of these matters can be found in Soares (2005), including a description of the sampled archaeological sites, as well as all the data obtained from our research concerning the variability of coastal upwelling off of Portugal and the regional reservoir ages. Sampling locations are shown in Figure 1.

\section{EXPERIMENTAL}

Samples were first cleaned by manually removing foreign material. Charcoal and wood samples were further decontaminated by acid/alkali/acid digestion. For bone samples, gelatin was extracted using the Longin method (Longin 1970). Marine shell samples were usually restricted to whole valves of the same species with no visual evidence of surface deterioration. Nevertheless, the outermost $30 \%$ by weight of the shells was discarded by controlled acid leaching $\left(0.5 \mathrm{M} \mathrm{HCl}\right.$ at $\left.25{ }^{\circ} \mathrm{C}\right)$. For some samples, where size allowed, controlled acid hydrolysis was used to separate approximately equal volumes of $\mathrm{CO}_{2}$ representative of the intermediate fraction and the inner fraction of the shells' carbonate structure.

We measured the ${ }^{14} \mathrm{C}$ content by means of the liquid scintillation technique (Soares 1989). Stable isotope enrichment values $\left(\delta^{13} \mathrm{C}\right)$ were determined for the $\mathrm{CO}_{2}$ gas produced at the initial stage of benzene synthesis.

${ }^{14} \mathrm{C}$ ages or the radiometric enrichment $\mathrm{D}^{14} \mathrm{C}$ were calculated in accordance with the definitions recommended by Stuiver and Polach (1977).

\section{RESULTS AND DISCUSSION}

Measurements of the ${ }^{14} \mathrm{C}$ contents of the terrestrial/marine pairs and the resulting $\Delta \mathrm{R}$ values are listed in Table 1. Following Stuiver and Braziunas (1993: Figure 15), $\Delta \mathrm{R}$ values were calculated by converting the terrestrial biosphere sample ${ }^{14} \mathrm{C}$ age from each archaeological context into a marine model age; this marine model age was then subtracted from the ${ }^{14} \mathrm{C}$ age of the associated marine shell sample to yield $\Delta \mathrm{R}$.

As already mentioned, we dated 2 or more samples of the same origin (e.g. samples of marine shells, each one comprising only 1 species) from the same stratigraphic level and context. A weighted mean was then calculated using $\mathrm{D}^{14} \mathrm{C}$ values, and a statistical criterion was established to determine if the value for a given sample fell within the limits established by the mathematical expression $A_{s}-A_{m} \leq 2 \sqrt{\sigma_{s}^{2}+\sigma_{m}^{2}}$, where $A_{s}$ is the median value for the given sample, $\sigma_{s}^{2}$ its associated variance, $A_{m}$ the group weighted mean, and $\sigma_{m}^{2}$ its associated variance. If the value falls outside the prescribed limits, it is rejected and a new weighted mean is calculated. 


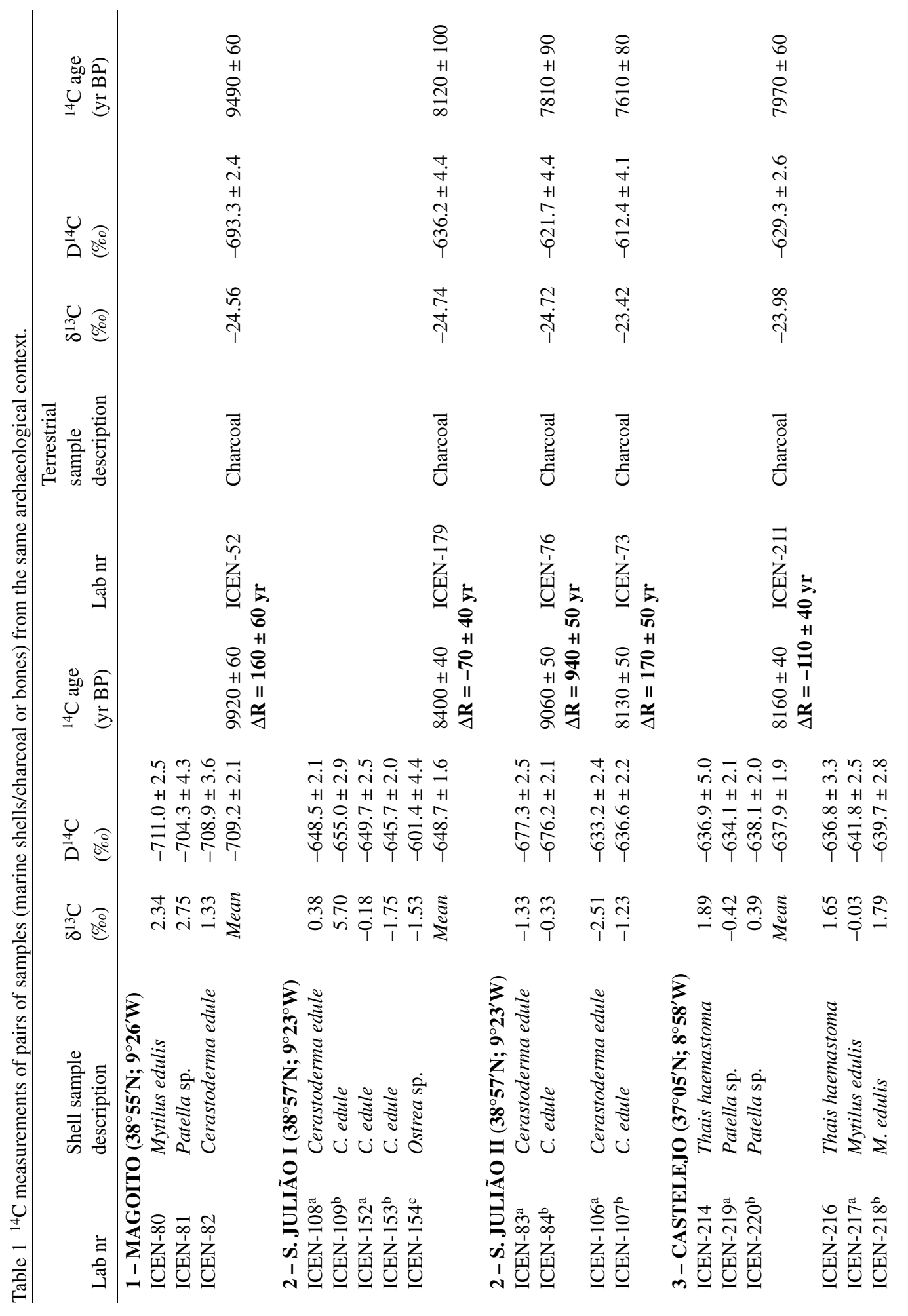




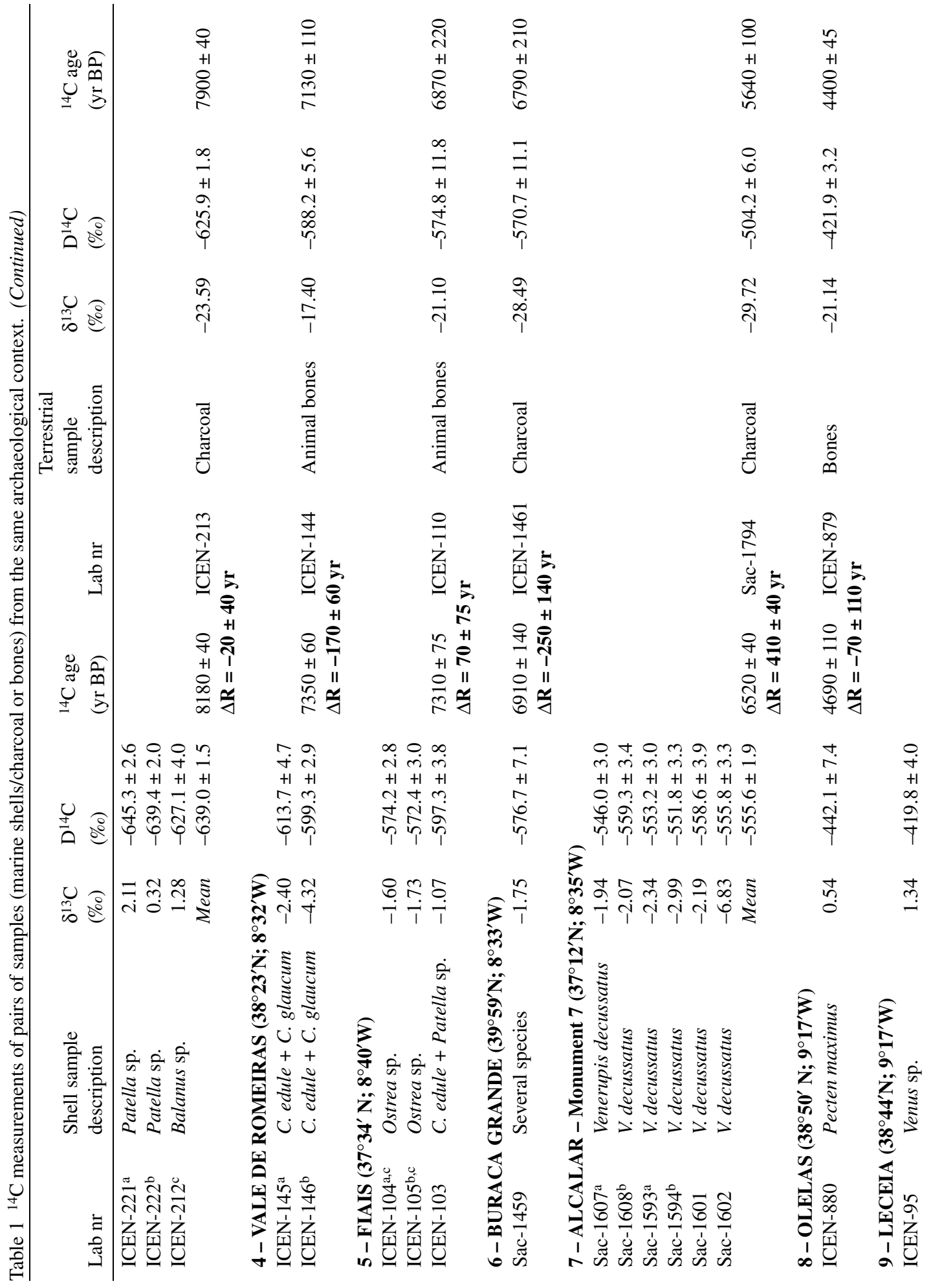




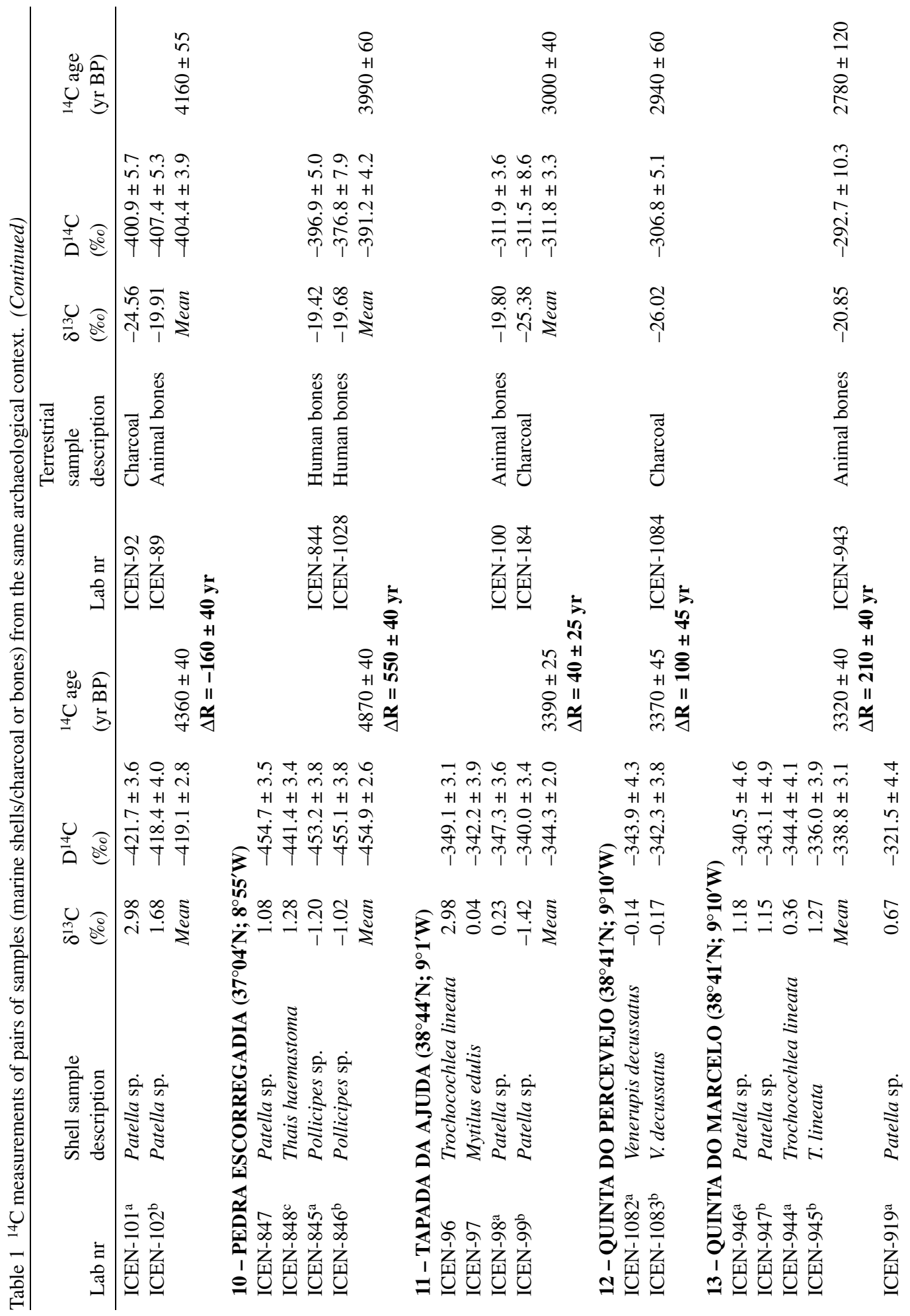




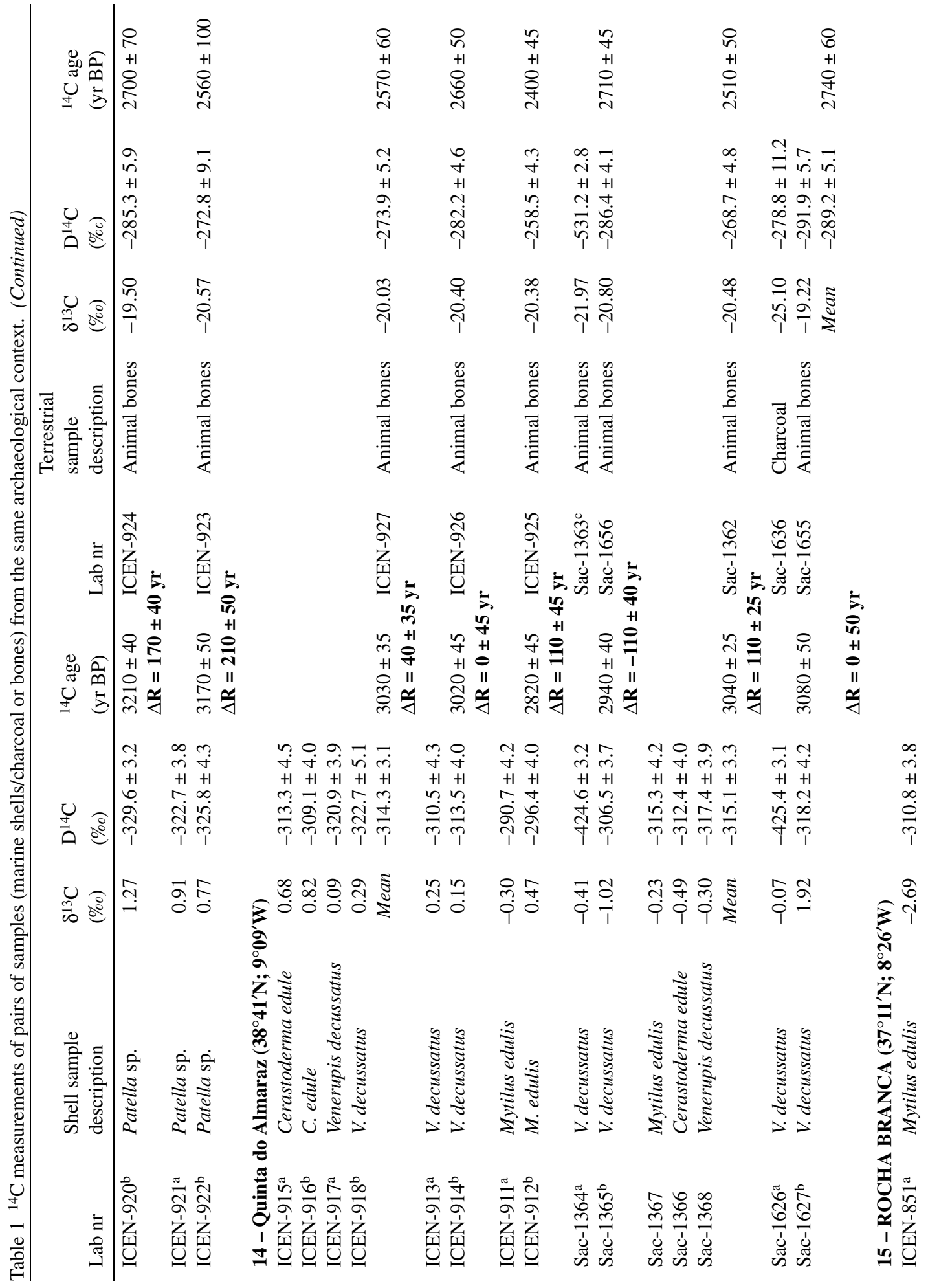




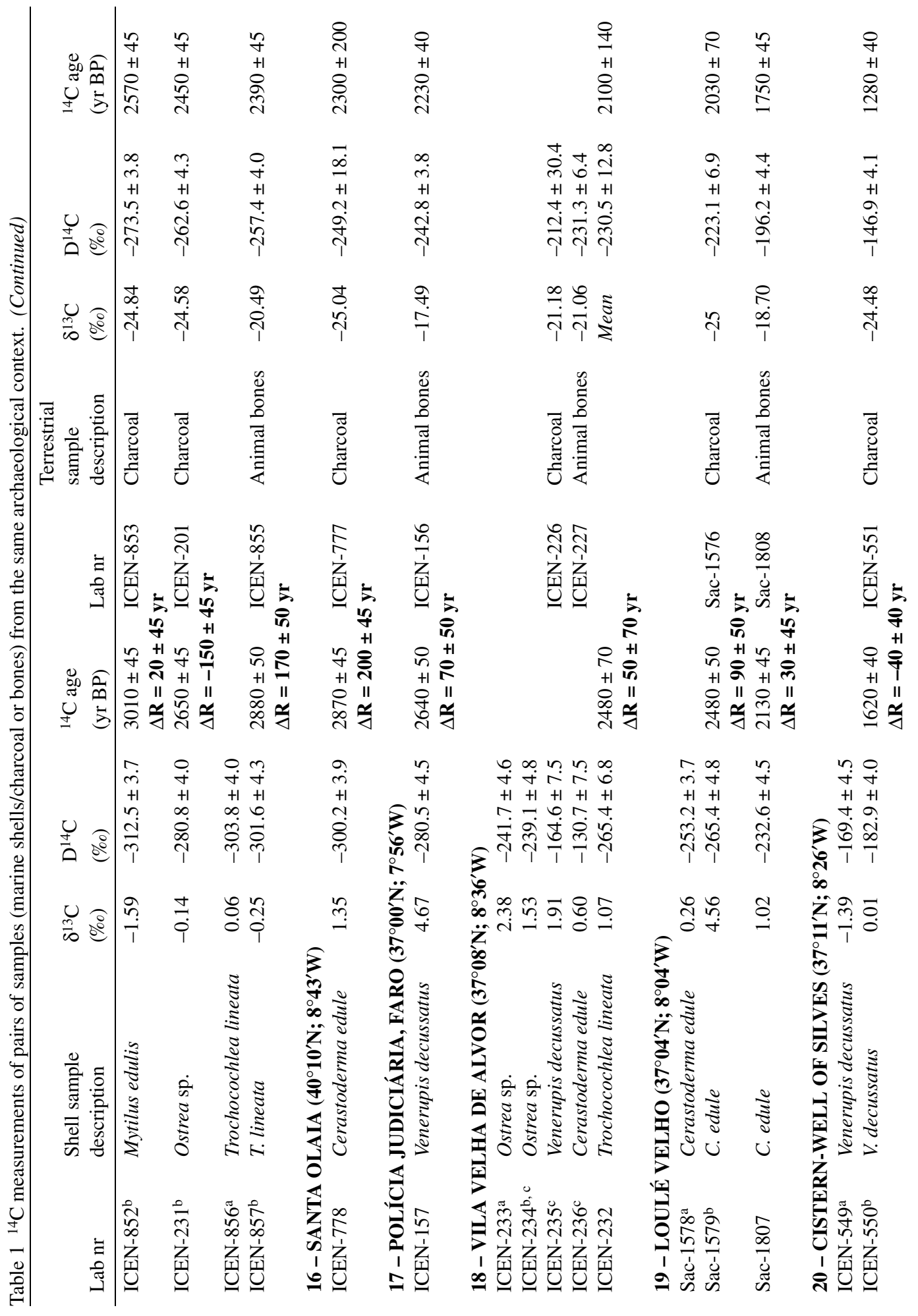




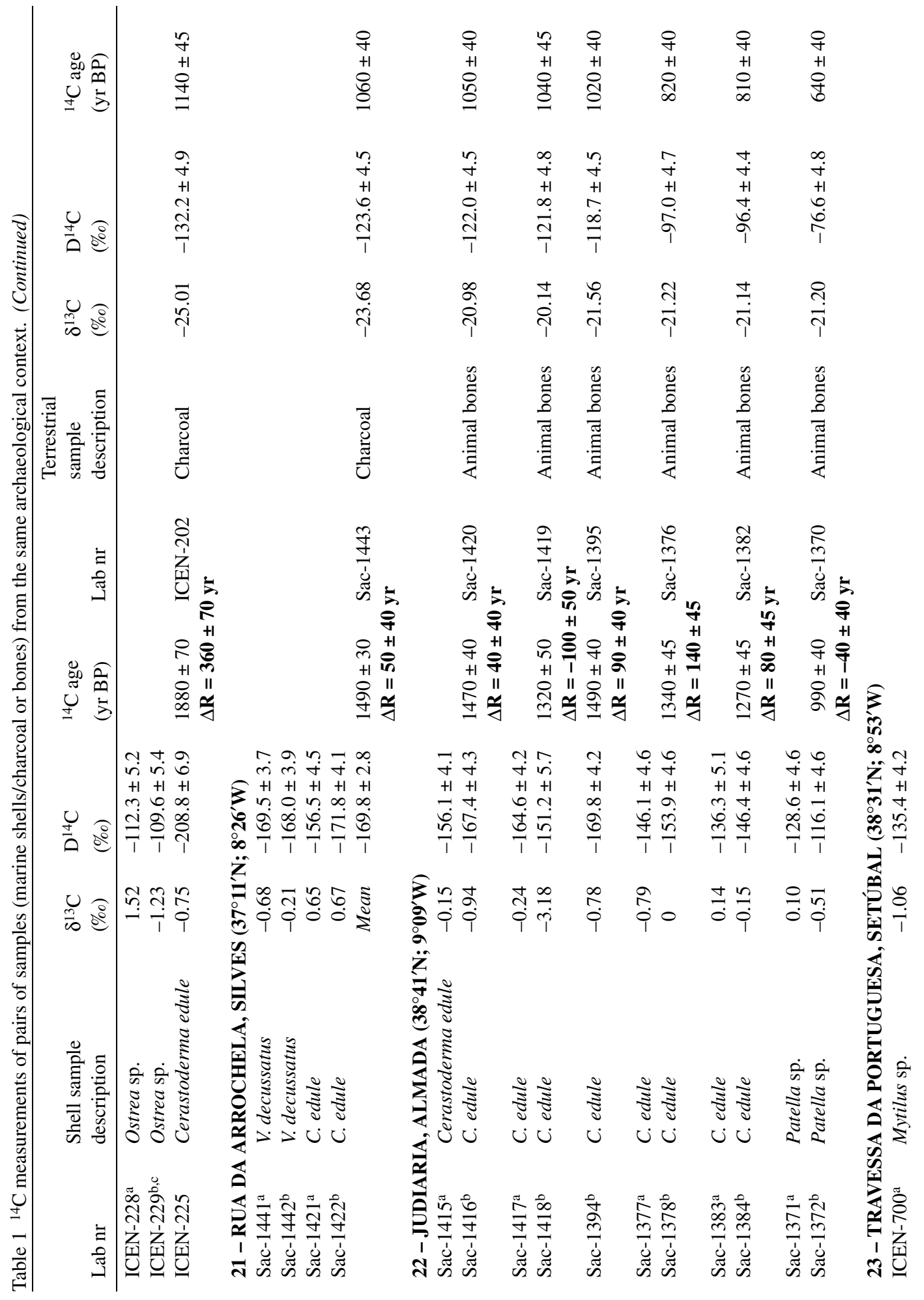




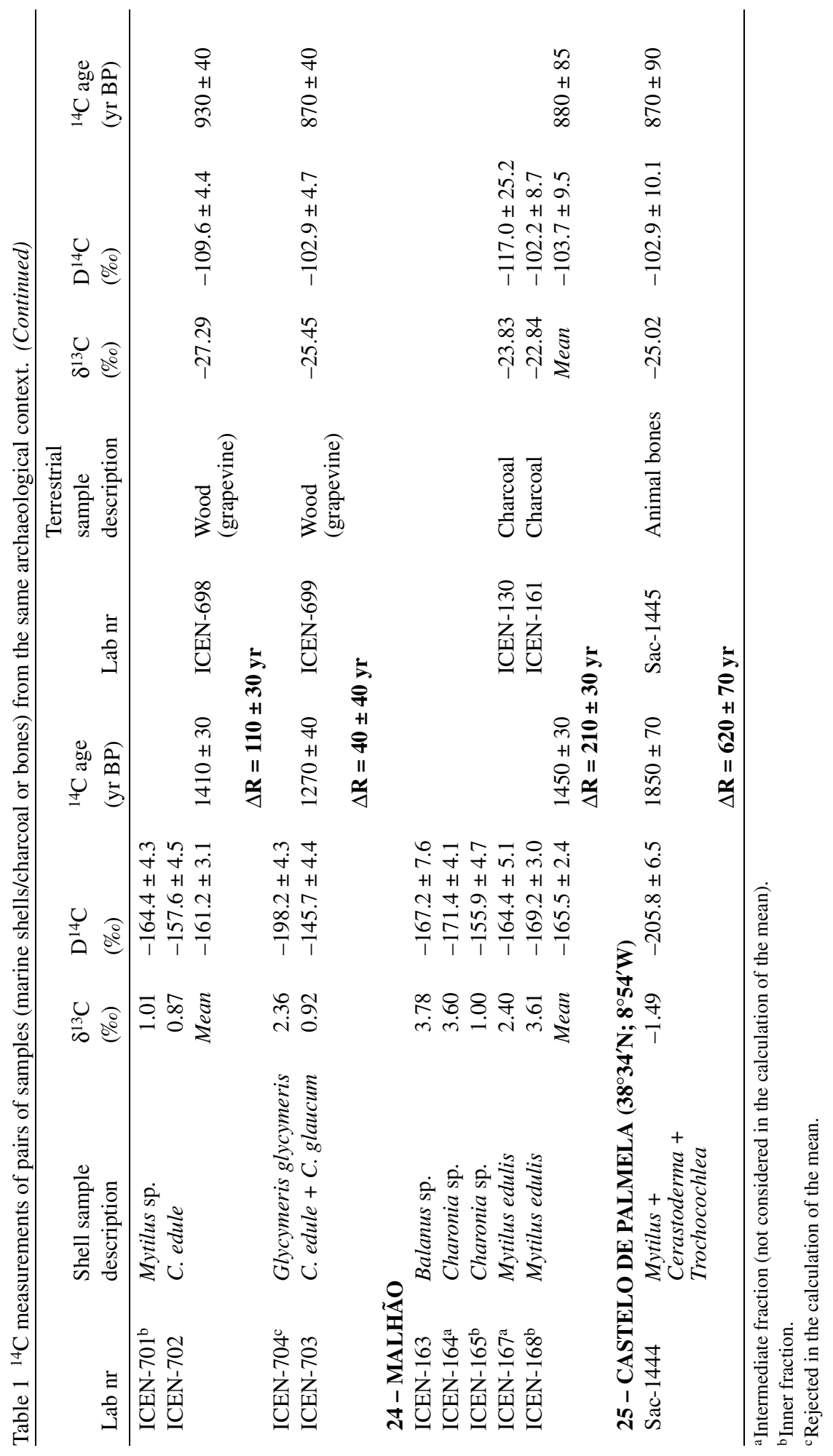


The mathematical constraint imposed upon the results allows us to verify (see Table 1) that the ${ }^{14} \mathrm{C}$ content of different contemporary shell species (at least those from mollusks usually consumed by people) were not influenced by the dietary or habitat preferences of the respective organisms (see e.g. the values for Tapada da Ajuda or Quinta do Almaraz at $2510 \pm 50 \mathrm{BP}$ ). Nevertheless, the values determined using samples of Ostrea are generally very different from those obtained using samples of other shell species (see results from S. Julião I, Fiais, Vila Velha de Alvor, and the cistern-well of Silves), and, in some cases, the age determined for the Ostrea sample is more recent than the age of the associated terrestrial material (e.g. from S. Julião I or from the cistern-well of Silves). Thus, these facts may be related to the dietary preference of $O$ strea, but the incorporation of materials (carbonates) of different ages into the shell during its diagenesis cannot be ruled out.

Only the value of $\mathrm{D}^{14} \mathrm{C}$ determined for the inner fraction of marine shell samples (when 2 fractions are obtained and analyzed) is taken into consideration for $\Delta \mathrm{R}$ calculation. The $\mathrm{D}^{14} \mathrm{C}$ value for the intermediate fraction is merely an index of reliability for the inner fraction $\mathrm{D}^{14} \mathrm{C}$ as are the inner and the intermediate fraction $\delta^{13} \mathrm{C}$ values. For uncontaminated marine samples, $\delta^{13} \mathrm{C}$ must be higher than $-3 \%$ (Keith and Anderson 1963).

In Table 2, the $\Delta \mathrm{R}$ values are presented for each archaeological context listed in decreasing chronological order. The context age was determined by using samples of terrestrial biosphere origin. These ages are presented as conventional ${ }^{14} \mathrm{C}$ dates and also as calendar dates using the program CALIB Rev 5.0.1 (Stuiver and Reimer 1993; Reimer et al. 2004).

Table 2 Reservoir effect values for the Portuguese coast.

\begin{tabular}{|c|c|c|c|c|}
\hline Archaeological site & $\begin{array}{l}{ }^{14} \mathrm{C} \text { age } \\
\text { (BP) }\end{array}$ & $\begin{array}{l}\mathrm{cal} \mathrm{BC/cal} \mathrm{AD}{ }^{\mathrm{a}} \\
(2 \sigma)\end{array}$ & $\begin{array}{l}\text { cal BPa } \\
(2 \sigma)\end{array}$ & $\begin{array}{l}\Delta \mathrm{R} \\
\left({ }^{14} \mathrm{C} \text { yr }\right)\end{array}$ \\
\hline Magoito & $9490 \pm 60$ & cal BC 9130-8630 & $10,580-11,080$ & $160 \pm 60$ \\
\hline S. Julião I & $8120 \pm 100$ & cal BC 7450-6710 & $8660-9400$ & $-70 \pm 40$ \\
\hline Castelejo & $7970 \pm 60$ & cal BC 7050-6690 & 8640-9000 & $-110 \pm 40$ \\
\hline Castelejo & $7900 \pm 40$ & cal BC 7030-6640 & $8590-8980$ & $-20 \pm 40$ \\
\hline S. Julião II & $7810 \pm 90$ & cal BC 7030-6470 & $8420-8980$ & $940 \pm 50$ \\
\hline S. Julião II & $7610 \pm 80$ & cal BC 6630-6260 & $8210-8580$ & $170 \pm 50$ \\
\hline Vale Romeiras & $7130 \pm 110$ & cal BC 6230-5780 & $7720-8180$ & $-170 \pm 60^{\mathrm{b}}$ \\
\hline Fiais & $6870 \pm 220$ & cal BC 6220-5380 & $7330-8160$ & $70 \pm 75$ \\
\hline Buraca Grande & $6790 \pm 210$ & cal BC 6070-5320 & 7270-8020 & $-250 \pm 140^{\mathrm{b}}$ \\
\hline Alcalar & $5640 \pm 100$ & cal BC 4720-4270 & $6220-6660$ & $410 \pm 40$ \\
\hline Olelas & $4400 \pm 45$ & cal BC 3320-2910 & $4860-5270$ & $-70 \pm 110^{b}$ \\
\hline Leceia & $4160 \pm 55$ & cal BC 2890-2580 & $4530-4840$ & $-160 \pm 40$ \\
\hline Pedra Escorregadia & $3990 \pm 60$ & cal BC 2840-2300 & $4250-4780$ & $550 \pm 40$ \\
\hline Tapada da Ajuda & $3000 \pm 40$ & cal BC 1390-1120 & $3070-3340$ & $40 \pm 25$ \\
\hline Quinta do Percevejo & $2940 \pm 60$ & cal BC 1370-980 & $2930-3320$ & $100 \pm 45$ \\
\hline Marcelo & $2780 \pm 120$ & cal BC $1370-670$ & $2620-3320$ & $210 \pm 40$ \\
\hline Quinta do Almaraz & $2740 \pm 60$ & cal BC $1020-800$ & $2750-2960$ & $0 \pm 50$ \\
\hline Quinta do Almaraz & $2710 \pm 45$ & cal BC 970-800 & $2750-2920$ & $-110 \pm 40^{\mathrm{b}}$ \\
\hline Marcelo & $2700 \pm 70$ & cal BC $1020-770$ & 2720-2970 & $170 \pm 40$ \\
\hline Quinta do Almaraz & $2660 \pm 50$ & cal BC $920-770$ & $2720-2870$ & $0 \pm 45$ \\
\hline Rocha Branca & $2570 \pm 45$ & cal BC $820-540$ & $2490-2770$ & $20 \pm 45$ \\
\hline Quinta do Almaraz & $2570 \pm 60$ & cal BC $840-420$ & $2370-2790$ & $40 \pm 35$ \\
\hline Marcelo & $2560 \pm 100$ & cal BC $900-410$ & $2360-2840$ & $210 \pm 50$ \\
\hline Quinta do Almaraz & $2510 \pm 50$ & cal BC $800-420$ & $2370-2740$ & $110 \pm 25$ \\
\hline Rocha Branca & $2450 \pm 45$ & cal BC $760-410$ & $2360-2700$ & $-150 \pm 45^{\mathrm{b}}$ \\
\hline
\end{tabular}


Table 2 Reservoir effect values for the Portuguese coast. (Continued)

\begin{tabular}{|c|c|c|c|c|}
\hline Archaeological site & $\begin{array}{l}{ }^{14} \mathrm{C} \text { age } \\
\text { (BP) }\end{array}$ & $\begin{array}{l}\text { cal BC/cal ADa } \\
(2 \sigma)\end{array}$ & $\begin{array}{l}\text { cal BPa } \\
(2 \sigma)\end{array}$ & $\begin{array}{l}\Delta \mathrm{R} \\
\left({ }^{14} \mathrm{C} \mathrm{yr}\right)\end{array}$ \\
\hline Quinta do Almaraz & $2400 \pm 45$ & cal BC $750-390$ & $2340-2700$ & $110 \pm 45$ \\
\hline Rocha Branca & $2390 \pm 45$ & cal BC $750-390$ & $2340-2700$ & $170 \pm 50$ \\
\hline Santa Olaia & $2300 \pm 200$ & cal BC 830-cal AD 120 & $1830-2780$ & $200 \pm 45$ \\
\hline Judiciária (Faro) & $2230 \pm 40$ & cal BC $390-200$ & $2150-2340$ & $70 \pm 50$ \\
\hline Vila Velha de Alvor & $2100 \pm 140$ & cal BC $410-$ cal AD 240 & $1710-2360$ & $50 \pm 70$ \\
\hline Loulé Velho & $2030 \pm 70$ & cal BC 340-cal AD 130 & $1820-2290$ & $90 \pm 50$ \\
\hline Loulé Velho & $1750 \pm 45$ & cal AD $140-400$ & $1550-1810$ & $30 \pm 45$ \\
\hline Poço-Cisterna & $1280 \pm 40$ & $\mathrm{cal}$ AD $\quad 660-860$ & $1090-1290$ & $-40 \pm 40$ \\
\hline Poço-Cisterna & $1140 \pm 45$ & cal AD $780-990$ & $960-1170$ & $360 \pm 70$ \\
\hline Arrochela & $1060 \pm 40$ & cal AD $890-1030$ & $920-1060$ & $50 \pm 40$ \\
\hline Judiaria & $1050 \pm 40$ & cal AD $890-1030$ & $920-1060$ & $40 \pm 40$ \\
\hline Judiaria & $1040 \pm 45$ & cal AD $890-1150$ & $800-1060$ & $-100 \pm 50^{\mathrm{b}}$ \\
\hline Judiaria & $1020 \pm 40$ & cal AD 900-1150 & $800-1050$ & $90 \pm 40$ \\
\hline Trav. Portuguesa & $930 \pm 40$ & cal AD 1020-1210 & $740-930$ & $110 \pm 30$ \\
\hline Malhão & $880 \pm 85$ & cal AD 1020-1280 & $670-940$ & $210 \pm 30$ \\
\hline Trav. Portuguesa & $870 \pm 40$ & cal AD $1040-1260$ & $700-910$ & $40 \pm 40$ \\
\hline Castelo de Palmela & $870 \pm 90$ & cal AD 1000-1280 & $670-950$ & $620 \pm 70$ \\
\hline Judiaria & $820 \pm 40$ & cal AD 1060-1280 & $670-890$ & $140 \pm 45$ \\
\hline Judiaria & $810 \pm 40$ & cal AD 1160-1280 & $670-790$ & $80 \pm 45$ \\
\hline Judiaria & $640 \pm 40$ & cal AD 1280-1400 & $550-670$ & $-40 \pm 40$ \\
\hline Portuguese coast & Modern & AD (1880-1940) & & $250 \pm 25$ \\
\hline
\end{tabular}

${ }^{a}$ Calendar dates are given by the intervals, the limits of which, rounded off to the nearest multiple of 10, correspond to the lower and upper limits of extreme intervals of the calibrated ${ }^{14} \mathrm{C}$ dates.

${ }^{\mathrm{b}} \Delta \mathrm{R}$ values of reduced reliability due to the fact that the marine samples were made up of shells collected in an estuarine system with a strong content of brackish water (Vale Romeiras) or of a mixture of shell species where the existence of individuals of different ages cannot be discarded (Buraca Grande); concerning Olelas and Quinta do Almaraz $(\Delta \mathrm{R}=-110 \pm 40)$, the contemporaneity between the samples from different reservoirs is not secure; and, finally, the marine sample from Rocha Branca $(\Delta \mathrm{R}=-150 \pm 45)$ was made up of Ostrea, which usually gives an anomalous result.

$\Delta \mathrm{R}$ values range from $940 \pm 50$ to $-160 \pm 40{ }^{14} \mathrm{C} \mathrm{yr}$, if data of reduced reliability are excluded. A very similar situation occurs at the northern coast of California, where results range from $870 \pm 90$ to $-170 \pm 90{ }^{14} \mathrm{C}$ yr (Ingram 1998). This considerable variation suggests a significant fluctuation in the strength of the Portuguese coastal upwelling, which may be the result of fluctuations in latitudinal migration of the subtropical front or of the North Atlantic Oscillation (the strength of northerly and northwesterly winds depends on these factors) or of the summer insolation (increase in summer insolation results in stronger sea breezes that enhance the northerly component of the wind).

If the $\Delta \mathrm{R}$ data determined for the Portuguese coast are plotted against time (Figure 2), 5 peaks can be observed, namely at $7810 \pm 90,5640 \pm 100,3990 \pm 60,1140 \pm 45$, and $870 \pm 90 \mathrm{BP}(8.42-8.98$, $6.22-6.66,4.25-4.79,0.96-1.17$, and $0.67-0.95 \mathrm{cal} \mathrm{kyr} \mathrm{BP}$, respectively). These $\Delta \mathrm{R}$ values are significantly higher than the modern value $(250 \pm 25 \mathrm{yr})$, while the remaining ones are lower. There are 3 hypotheses that may explain those peaks: i) they are outliers; ii) they reflect a very strong upwelling; or iii) they are correlated with Bond events (those high values may be due to the huge amounts of ${ }^{14} \mathrm{C}$-depleted fresh water from ice sheets- "many thousands of years of stored precipitation," following Teller et al. [2002] — that were injected in the North Atlantic at high latitudes). Further detailed research is needed to validate any of these hypotheses. 


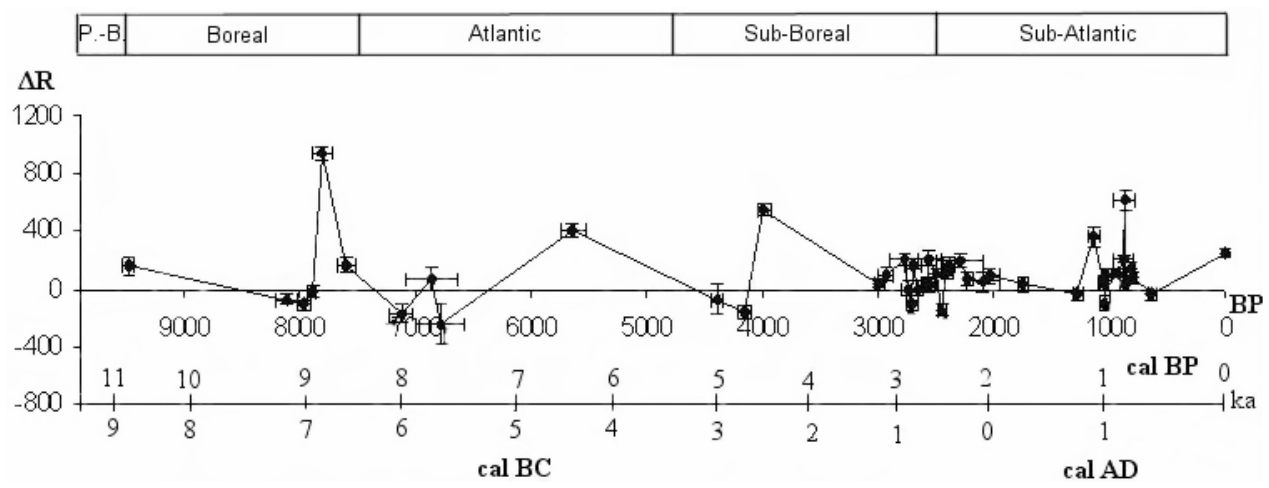

Figure 2 The variability in ocean reservoir effect off the Portuguese coast during the Holocene. $\Delta \mathrm{R}( \pm 1 \sigma)$ values are plotted versus terrestrial ${ }^{14} \mathrm{C}$ ages $( \pm 1 \sigma)$.

The other $\Delta \mathrm{R}$ values are certainly related to the strength of the coastal upwelling prevailing at the corresponding time. However, as we mention above, the "old wood effect" problem may apply for some of our dated charcoal samples, which may explain the low or negative $\Delta \mathrm{R}$ values. Nevertheless, 2 associated terrestrial samples (see Table 1) from Leceia (1 of charcoal, 1 of bones) were ${ }^{14} \mathrm{C}$ dated, and the results are not statistically different; the $\Delta R$ value is negative $\left(\Delta R=-160 \pm 40{ }^{14} \mathrm{C} \mathrm{yr}\right)$. From Olelas, Quinta do Almaraz (at $2710 \pm 45 \mathrm{BP}$ ), and Judiaria (at 1040 $\pm 45 \mathrm{BP}$ and $640 \pm 40 \mathrm{BP}$ ), only 1 sample of bones from each site (as representative of the terrestrial biosphere in the pair) was dated and the calculated $\Delta \mathrm{R}$ values are also negative. Two associated samples of terrestrial material (bones and charcoal) from Tapada da Ajuda, Quinta do Almaraz (2740 \pm 60 BP), and Vila Velha do Alvor were also dated. The results were statistically similar for each pair, and the calculated $\Delta \mathrm{R}$ values were positive, although low. All this suggests that the old wood effect problem was probably not very important for the ${ }^{14} \mathrm{C}$ dating of the sampled Portuguese archaeological contexts, and low or negative $\Delta \mathrm{R}$ values correspond with a weak, or even nonexistent, coastal upwelling off the Portuguese coast.

Looking at the values in Table 2 (and Figure 2) some other inferences can be drawn:

1. During the Preboreal, an upwelling regime may have occurred along the Portuguese coast (see $\Delta \mathrm{R}$ value for Magoito).

2. During the Boreal cold climate, a weak or nonexistent coastal upwelling can be assigned to the Portuguese coast (negative $\Delta \mathrm{R}$ values).

3. Four values for $\Delta \mathrm{R}$ were obtained in the Atlantic period. Nevertheless, 2 of them are less reliable (see Table 1) since in one case (Vale Romeiras) the marine samples came from shells collected in an estuarine system with a strong content of brackish water, and in the other case (Buraca Grande) from a mixture of shell species where the existence of individuals of different ages cannot be discounted. The remaining 2 values (from S. Julião II and Fiais) suggest an existing coastal upwelling, perhaps weaker than the modern one.

4. Between the beginning of the Subboreal and $4000 \mathrm{BP}$, only $1 \Delta \mathrm{R}$ value was obtained. The negative value suggests that a weak or nonexistent coastal upwelling prevailed during this period.

5. Between 4000 and $3000 \mathrm{BP}$, no $\Delta \mathrm{R}$ values were determined for the Portuguese coast, if we exclude the value for Pedra Escorregadia, i.e. one of the peaks referred to above. Nevertheless, pollen diagrams from peat deposits located in the Setúbal-Sines region (SW Portugal) for this time interval indicate favorable conditions for a more sclerophyllous vegetation type than previously existed and for a hiatus in peat accumulation, suggesting a drier and warmer climate 
(Mateus 1992; Mateus and Queiroz 1993). These climatic conditions would favor an enhanced coastal upwelling with corresponding high $\Delta \mathrm{R}$ values. Thus, the referred $\Delta \mathrm{R}$ peak $\left(550 \pm 40{ }^{14} \mathrm{C}\right.$ yr at $3990 \pm 60 \mathrm{BP}$ ) may be correlated with this supposed enhanced coastal upwelling.

6. From 3000 to $\sim 600 \mathrm{BP}$, more than $30 \Delta \mathrm{R}$ values were determined. These values suggest a weaker upwelling than exists today-the calculated weighted mean for $\Delta \mathrm{R}$ being $95 \pm 15{ }^{14} \mathrm{C}$ yr.

7. The modern value of $\Delta \mathrm{R}\left(250 \pm 25{ }^{14} \mathrm{C} \mathrm{yr}\right)$ was determined using shells from marine mollusks collected alive along the Portuguese coast between 1886 and 1937 (Soares 1993), i.e. just after the Little Ice Age. Recent research suggests that the Portuguese coastal upwelling regime has weakened since the 1940s (Lemos and Pires 2004).

All these data suggest that during the Holocene, a more dynamic upwelling regime prevailed off the Portuguese coast than had been previously thought and, consequently, the Holocene climate over the Iberian Peninsula may exhibit a significant variability, which agrees with recent studies for the North Atlantic area (Bond et al. 1997, 2001; Broecker 2000; deMenocal 2000; McDermott et al. 2001).

\section{CONCLUSIONS}

Reservoir ages can provide information concerning the intensity of coastal upwelling and mixing processes in regions of the ocean strongly influenced by this phenomenon. A record of past reservoir ages is preserved in the ${ }^{14} \mathrm{C}$ ages of contemporary marine and terrestrial material. ${ }^{14} \mathrm{C}$ dating of more than 100 samples of marine shells and associated charcoal or bone from Portuguese archaeological sites with ages spanning the Holocene show that the $\Delta \mathrm{R}$ values range from $940 \pm 50$ to $-160 \pm 40$ ${ }^{14} \mathrm{C}$ yr, suggesting significant fluctuations in the strength of Portuguese coastal upwelling. Most of these values are lower than the modern value $\left(250 \pm 25{ }^{14} \mathrm{C} \mathrm{yr}\right)$. Periods of low $\Delta \mathrm{R}$ may indicate periods during which rates of upwelling were lower than at present. Although some of these periods are poorly sampled, as are those from the beginning of the Holocene until the end of the Atlantic, the few $\Delta \mathrm{R}$ results suggest an upwelling of weak intensity or, at the least, one that was less strong than it is today. The time frame from 3000 to $\sim 600 \mathrm{BP}-$ a well-sampled period including more than 30 $\Delta \mathrm{R}$ values with a weighted mean of $95 \pm 15{ }^{14} \mathrm{C} \mathrm{yr}$ - seems also to be a period of upwelling lower than at present. Conversely, between 4000 and $3000 \mathrm{BP}$, we obtained only $1 \Delta \mathrm{R}$ value that is higher than the modern one, suggesting a period of higher coastal upwelling along the Portuguese coast. All these data suggest that the Portuguese coastal upwelling exhibits a significant variability during the Holocene, which may be coupled with climate variability over the Iberian Peninsula.

\section{ACKNOWLEDGMENTS}

We wish to express our gratitude to Dr Paula Reimer for her careful review of the manuscript, valuable comments, and suggestions; also thanks to Dr Simon Davis for revising the English text.

\section{REFERENCES}

Abrantes F. 2000. 200000 yr diatom records from Atlantic upwelling sites reveal maximum productivity during LGM and a shift in phytoplankton community structure at 185000 yr. Earth and Planetary Science Letters 176:7-16.

Abrantes F, Loncaric N, Moreno J, Mil-Homens M, Pflauman U. 2001. Paleoceanographic conditions along the Portuguese Margin during the last $30 \mathrm{ka}$ : a multiple proxy study. Comunicações do Instituto
Geológico e Mineiro 88:161-84.

Bond G, Showers W, Cheseby M, Lotti R, Almasi P, deMenocal P, Priore P, Cullen H, Hadjas I, Bonani G. 1997. A pervasive millennial-scale cycle in North Atlantic Holocene and glacial climates. Science 278: 1257-66.

Bond G, Kromer B, Beer J, Muscheler R, Evans MN, Showers W, Hoffmann S, Lotti-Bond R, Hajdas I, Bonani G. 2001. Persistent solar influence on North At- 
lantic climate during the Holocene. Science 294: 2130-6.

Broecker WS. 2000. Abrupt climate change: causal constraints provided by the paleoclimate record. EarthScience Reviews 51:137-54.

Diffenbaugh NS, Sloan LC, Snyder MA. 2003. Orbital suppression of wind-driven upwelling in the California Current at 6 ka. Paleoceanography 18: 1051, doi: 10.1029/2002PA000865.

Ferreira DB. 1984. Le systeme climatique de l'upwelling Ouest Ibérique [report \#19 of the Linha de Acção de Geografia Física]. Lisbon: Centro de Estudos Geográficos. INIC. $92 \mathrm{p}$.

Fiúza AFG. 1982. The Portuguese coastal upwelling system. In: Actual Problems of Oceanography in Portugal. Lisbon: Junta Nacional de Investigaçao Cientifica e Tecnológia. p 45-71.

Fiúza AFG. 1983. Upwelling patterns off Portugal. In: Suess E, Thiede J, editors. Coastal Upwelling, Its Sediment Record. New York: Plenum. p 85-98.

Fiúza AFG, Macedo ME, Guerreiro MR. 1982. Climatological space and time variation of the Portuguese coastal upwelling. Oceanologica Acta 5:31-40.

Ingram BL. 1998. Differences in radiocarbon age between shell and charcoal from a Holocene shellmound in northern California. Quaternary Research 49(1): $102-10$.

Keith ML, Anderson GM. 1963. Radiocarbon dating: fictitious results with mollusk shells. Science 141:634-7.

Lemos RT, Pires HO. 2004. The upwelling regime off the west Portuguese coast. International Journal of Climatotology 24:511-24.

Longin R. 1970. Extraction du collagene des os fossils pour leur datation par la methode du Carbone 14 . [Thesis $3^{\mathrm{e}}$ cycle]. Lyon: Faculté des Sciences de l'Université de Lyon. 70 p. In French.

Mateus JE. 1992. Holocene and present-day ecosystems of the Carvalhal Region, southwest Portugal [ $\mathrm{PhD}$ dissertation]. Utrecht: University of Utrecht. 184 p.

Mateus JE, Queiroz PF. 1993. Os estudos de vegetação quaternária em Portugal; contextos, balanço de resultados, perspectivas. In: Carvalho GS, Ferreira A, Senna-Martínez JC, editors. O Quaternário em Portugal. Balanço e Perspectivas. Lisbon: Colibri. p 10531. In Portuguese.

McDermott F, Mattey DP, Hawkesworth C. 2001. Centennial-scale Holocene climate variability revealed by a high-resolution speleothem $\delta^{18} \mathrm{O}$ record from SW Ireland. Science 294:1328-31.

deMenocal P, Ortiz J, Guilderson T, Sarnthein M. 2000. Coherent high- and low-latitude climate variability during the Holocene warm period. Science 288:2198202.

Peliz Á, Rosa TL, Santos AMP, Pissarra JL. 2002. Fronts, jets, and counter-flows in the Western Iberian upwelling system. Journal of Marine Systems 35(1-2): 61-77.
Reimer PJ, Baillie MGL, Bard E, Bayliss A, Beck JW, Bertrand CJH, Blackwell PG, Buck CE, Burr GS, Cutler KB, Damon PE, Edwards RL, Fairbanks R, Friedrich M, Guilderson TP, Hogg AG, Hughen KA, Kromer B, McCormac G, Manning S, Ramsey CB, Reimer RW, Remmele S, Southon JR, Stuiver M, Talamo S, Taylor FW, van der Plicht J, Weyhenmeyer CE. 2005. IntCal04 terrestrial radiocarbon age calibration, 0-26 cal kyr BP. Radiocarbon 46(3):1029-58.

Relvas P, Barton ED. 2000. Surface structure of the coastal ocean off SW Iberia during an upwelling relaxation. In: Proceedings of the 3rd Symposium on the Iberian Atlantic Margin. 25-27 September 2000. p 177-8.

Sánchez R, Relvas P. 2003. Breakup of the upwelling circulation off Cape St Vincent, SW Portugal. Thalassas 19:125-6.

Soares AMM. 1989. O efeito de reservatório oceânico nas aguas costeiras de Portugal continental. Sacavém: Instituto de Ciências e Engenharia Nucleares (Instituto Nacional de Engenharia e Tecnologia Industrial). 135 p. In Portuguese.

Soares AMM. 1993. The ${ }^{14} \mathrm{C}$ content of marine shells: evidence for variability in coastal upwelling off Portugal during the Holocene. In: Isotope Techniques in the Study of Past and Current Environmental Changes in the Hydrosphere and the Atmosphere. Vienna: International Atomic Energy Agency (IAEA). p 471-85.

Soares AMM. 2005. Variabilidade do "Upwelling" costeiro durante o Holocénico nas Margens Atlânticas Ocidental e Meridional da Península Ibérica [PhD dissertation]. Faro: Faculdade de Ciências do Mar e do Ambiente, Universidade do Algarve.

Stuiver M, Braziunas TF. 1993. Modeling atmospheric ${ }^{14} \mathrm{C}$ influences and ${ }^{14} \mathrm{C}$ ages of marine samples to 10,000 BC. Radiocarbon 35(1):137-89.

Stuiver M, Polach HA. 1977. Discussion: reporting of ${ }^{14} \mathrm{C}$ data. Radiocarbon 19(3):355-63.

Stuiver M, Reimer PJ. 1993. Extended ${ }^{14} \mathrm{C}$ database and revised CALIB $3.0{ }^{14} \mathrm{C}$ age calibration. Radiocarbon 35(1):215-30.

Stuiver M, Pearson GW, Braziunas T. 1986. Radiocarbon age calibration of marine samples back to $9000 \mathrm{cal} \mathrm{yr}$ BP. Radiocarbon 28(2B):980-1021.

Teller JT, Leverington DW, Mann JD. 2002. Freshwater outbursts to the oceans from glacial Lake Agassiz and their role in climate change during the last deglaciation. Quaternary Science Reviews 21:879-87.

Vargas JM, García-Lafuente J, Delgado J, Criado F. 2003. Seasonal and wind-induced variability of sea surface temperature patterns in the Gulf of Cádiz. Journal of Marine Systems 38:205-19.

Wooster WS, Bakun A, McClain DR. 1976. The seasonal upwelling cycle along the eastern boundary of the North Atlantic. Journal of Marine Research 34:13141. 